\title{
Noise Exposure and Otological Morbidity in Military Musicians in Cotonou
}

\author{
Alexis AWC do Santos Zounon ${ }^{*}$, Marius Claude Flatin², Bignon Losdia Gypsy Wannou1, \\ Ulrich Bidossessi Vodouhe1, François Avakoudjo1, Wassi Adjibabi1, \\ Bernadette Yehouessi-Vignikin ${ }^{1}$
}

\footnotetext{
${ }^{1}$ Department of Surgery and Surgical Specialties, Faculty of Sciences and Health, University of Abomey-Calavi, Abomey-Calavi, Benin

${ }^{2}$ Department of Surgery and Surgical Specialties, Faculty of Medicine, University of Parakou, Parakou, Benin

Email: *azdosantos@yahoo.fr
}

How to cite this paper: do Santos Zounon, A.A., Flatin, M.C., Wannou, B.L.G., Vodouhe, U.B., Avakoudjo, F., Adjibabi, W. and Yehouessi-Vignikin, B. (2022) Noise Exposure and Otological Morbidity in Military Musicians in Cotonou. International Journal of Otolaryngology and Head \& Neck Surgery, 11, 39-55.

https://doi.org/10.4236/ijohns.2022.111006

Received: December 20, 2021

Accepted: January 23, 2022

Published: January 26, 2022

Copyright (c) 2022 by author(s) and Scientific Research Publishing Inc. This work is licensed under the Creative Commons Attribution International License (CC BY 4.0).

http://creativecommons.org/licenses/by/4.0/

\begin{abstract}
Introduction: Military musicians are subjected to a double risk of noise related to the use of combat weapons and then to the use of musical instruments. The objective of this study was to assess the otological damage of military music professionals in Cotonou. Methods: This was an analytical crosssectional study carried out from July 15 to November 15, 2019. It focused on soldiers from the Music Squadron and the first Motorized Intervention Battalion of Camp Guézo in Cotonou. Results: 110 soldiers were included. The mean age was $34.3 \pm 6.2$ years. The sex ratio was 17.3. The instruments used were wind $(74.5 \%)$, percussion $(23.6 \%)$ and string $(1.8 \%)$. The average length of service in the Music Squadron was $11.5 \pm 6.7$ years with extremes of 1 year and 25 years. They practiced military music for an average of 4.58 hours per day for 4 days per week. The mean sonometric measurement during training ranged from $89.1 \mathrm{~dB}(\mathrm{~A})$ to $116.4 \mathrm{~dB}(\mathrm{~A})$. Hearing loss was predominant in the military musicians group and was mild degree bilaterally $(\mathrm{p}=0.002)$ and perceptual type $(p=0.007)$. Conclusion: Military musicians are exposed to high noise levels, putting them at risk of developing hearing problems that may limit their performance. The main otological morbidity found was hearing loss associated with a few cases of tinnitus and headache.
\end{abstract}

\section{Keywords}

Occupational Hearing Loss, Otologic Morbidity, Military Musicians, Benin

\section{Introduction}

Saint François de Sales used to say "Noise does not do good, good does not make 
noise" to signify the nuisances that can be generated by prolonged, repeated or intensive noise exposure. Recognized as a cause of occupational disease since 1963 in France, noise impacts health, particularly hearing. According to the World Health Organization (WHO), noise is the second leading cause in the world of onset deafness in adults after presbycusis and $16 \%$ of hearing loss is linked to occupational noise exposure [1]. It is estimated that 466 million people $(6.1 \%$ of the world population) live with a disabling hearing loss worldwide, with a predominance of $93 \%$ among adults [2]. Noise-induced hearing loss is underestimated [3]. Military musicians are subject to a double sound risk. This risk is linked to the use of combat weapons and the use of musical instruments [4]. The objective of the present study was to report the otological damage in military musicians in Cotonou.

\section{Method}

This was a cross-sectional, analytical study that took place from July 15 to November 15, 2019. It focused on military personnel from the Music Squadron (Exposed) and the First Motorized Intervention Battalion of Camp Guézo (Controls) in Cotonou. The controls were chosen because they were supposed to be exposed to low levels of noise at work. The military personnel included in our study were under 50 years of age. The census was exhaustive at the level of the exposed. Our study included the same number of military personnel in the control group. These soldiers were selected by a simple random survey.

Data were collected using a questionnaire. A careful questioning allowed us to specify the socio-demographic, professional, extra-professional characteristics, the antecedents and the elements of sound exposure. Each soldier surveyed then underwent an Oto-Rhino-Laryngological (ENT) somatic examination by an ENT doctor, followed by a preliminary tonal audiometry performed in a center approved for auditory explorations "Centre Entendre Bénin".

The diagnostic audiometries were performed using a type 3 interacoustic diagnostic audiometer model AD 229B in a soundproof room, equipped with rubber headphones, an ossivibrator, two loudspeakers, an answering machine, a microphone, and two light sources. Sound measurements were made with a digital sound level meter (METERK Version MK09-EN-00 with LCD screen) in the non-soundproofing rehearsal room. The measurements were taken during group training for fifteen to sixty minutes. The data were entered using a data entry mask designed on EpiData 3.1 software with a data entry control and verification program. Statistical analysis was performed with R 3.6.0 software. Statistical associations were sought using Pearson's Chi ${ }^{2}$ test or Fisher's exact test and Student's $t$ test as appropriate. The significance level was set at $5 \%$.

This study was conducted with the approval of the Beninese military authorities and the free and informed consent of the respondents. The confidentiality of the data was rigorously respected, as was anonymity. 


\section{Results}

\subsection{Coverage Rate}

The exposed group consisted of 70 military musicians. Finally, 55 military musicians were able to participate in the study in the exposed group because 15 of them were not available, for a coverage rate of $78.6 \%$.

The control group consisted of 55 non-musicians from the First Motorized Intervention Battalion.

\subsection{Socio-Demographic Parameters}

Of a total of 110 military personnel surveyed, the mean age was $34.3 \pm 6.2$ years (range 26 - 50 years). The mean age was $35.9 \pm 7.0$ years and $32.7 \pm 4.8$ years for the exposed and control groups, respectively. In the exposed group, there were fewer young soldiers compared to controls $(54.5 \%$ were under 35 years of age versus $67.3 \%$ ). The sex ratio was 17.3 i.e. 10 men for a woman in the exposed group and 54 men for a woman in the control group. The exposed group was older than the controls (56.4\% versus $47.3 \%$ ). The two groups were not statistically different with respect to age, gender and length of time in Benin army. Table 1 presents the socio-demographic and professional characteristics of the military personnel surveyed.

\subsection{Noise Exposure}

Sound exposure concerned exclusively the exposed soldiers. Musical instruments were "wind instruments" in $74.5 \%$, "percussion" in $23.6 \%$ and "string instruments" in $1.8 \%$. The wind instruments were bass, trumpet, bugle, trombone and

Table 1. Socio-demographic and professional characteristics of the military personnel surveyed.

\begin{tabular}{cccc}
\hline & $\begin{array}{c}\text { Exposed } \\
\mathbf{n}(\%)\end{array}$ & $\begin{array}{c}\text { Controls } \\
\mathbf{n}(\%)\end{array}$ & p-value \\
\hline $\begin{array}{c}\text { Mean age (years) } \\
\text { Age (years) }\end{array}$ & $35.9 \pm 7.0$ ans & $32.7 \pm 4.8$ ans & $0.070^{\star *}$ \\
$<35$ & $30(54.5)$ & $37(67.3)$ & $0.171^{\star}$ \\
$\geq 35$ & $25(45.4)$ & $18(32.7)$ & \\
Gender & & & $0.208^{*}$ \\
Male & $50(90.9)$ & $54(98.2)$ & \\
Female & $05(9.1)$ & $01(1.8)$ & \\
Length of service in army & & & $0.340^{*}$ \\
$\leq 10$ & $24(43.6)$ & $29(52.7)$ & \\
$>10$ & $31(56.4)$ & $26(47.3)$ & \\
Total & $55(100.0)$ & $55(100.0)$ & \\
\hline
\end{tabular}

*Peason's Chi-squared Test; ${ }^{\star \star}$ Student’s Test. 
saxophone. Among the percussion instruments were the bass drum, the drum and the drum set. The stringed instrument used was the guitar.

More than a third of the military musicians (36.4\%) had been in the music squadron for 5 to 10 years. The average length of service in the music squadron was $11.5 \pm 6.7$ years with extremes of 1 and 25 years. On average, military musicians practiced music for 4 days per week with extremes of 2 to 6 days. The average daily occupational noise exposure was estimated to be $4.6 \pm 0.8$ hours, ranging from 4.1 to 5.1 hours. None of the musicians used personal hearing protection equipment (PPE) on a routine basis.In spite of the professional exposure, it was noted that almost all of the military musicians (92.7\%) were involved in a musical activity outside the music squadron, in particular in a church choir (Table 2).

Table 2. Professional and extra-professional characteristics of the soldiers surveyed.

\begin{tabular}{|c|c|c|}
\hline & Number (n) & Percentage (\%) \\
\hline \multicolumn{3}{|l|}{ Musical instruments } \\
\hline String instruments ${ }^{\star}$ & 1 & 1.8 \\
\hline Percussion $^{\star *}$ & 13 & 23.6 \\
\hline Wind instruments $* * *$ & 41 & 74.5 \\
\hline \multicolumn{3}{|l|}{ Seniority in the Music Squadron (years) } \\
\hline$\leq 5$ & 10 & 18.2 \\
\hline$] 5-10]$ & 20 & 36.4 \\
\hline ]10 - 15] & 9 & 16.4 \\
\hline ]15 - 20] & 9 & 16.4 \\
\hline$] 20-25]$ & 7 & 12.7 \\
\hline \multicolumn{3}{|l|}{ Duration of professional music practice (days) } \\
\hline$<3$ & 6 & 10.9 \\
\hline$[3-4[$ & 8 & 14.5 \\
\hline$[4-5[$ & 19 & 34.5 \\
\hline$[5-6[$ & 5 & 9.09 \\
\hline$[6-7[$ & 12 & 21.8 \\
\hline$[7-8[$ & 1 & 1.81 \\
\hline$\geq 8$ & 4 & 7.3 \\
\hline Average daily occupational noise exposure (hours) & $4.6 \pm 0.8 \mathrm{Ext}$ & rêmes: $4.1 \& 5.1$ \\
\hline \multicolumn{3}{|l|}{ Wearing of hearing PPE } \\
\hline Yes & 0 & 100.0 \\
\hline No & 55 & 0.0 \\
\hline \multicolumn{3}{|l|}{ Extra-professional music practice } \\
\hline No & 4 & 7.3 \\
\hline Yes & 51 & 92.7 \\
\hline
\end{tabular}

${ }^{\star B}$ Bass, trumpet, bugle, trombone, saxophone; ${ }^{* *}$ Bass drum, drums and drumset; ${ }^{* * *}$ Guitar. 


\section{Noise level}

The average noise level during training ranged from $89.1 \mathrm{~dB}(\mathrm{~A})$ to $116.4 \mathrm{~dB}$ (A).

\subsection{Clinical Parameters}

\section{- Anamnesis}

No service members reported a history of long-term ototoxic drug use, head injury, nagging or repeated otologic infections, tumor, or otologic surgery.

\section{- Functional signs}

Hearing loss was the most common and most important complaint in the exposed group ( $34.6 \%$ vs. $7.3 \%)$. The exposed group was 6.73 times more likely to have a hearing loss than the controls (Table 3).

\section{- Physical examination}

Otoscopic follow-up noted one case of otitis externa and one case of acute otitis media in the exposed soldiers. ENT examination remained normal in all soldiers in the control group. The otitis externa was treated locally with anti-inflammatory drops with a good clinical evolution. The otalgia, redness and congestion of the external acoustic meatus involved improved within eight days. The case of acute

Table 3. Morbidities associated with noise exposure.

\begin{tabular}{|c|c|c|c|c|c|}
\hline & Exposed & Controls & OR & CI95\% & p-value \\
\hline \multicolumn{6}{|l|}{ Hearing loss } \\
\hline No & $32(58.2 \%)$ & $51(92.7 \%)$ & 1 & & \\
\hline Yes & $23(41.8 \%)$ & $4(7.3 \%)$ & 9.16 & [3.18 - 33.5] & $<0.001^{*}$ \\
\hline \multicolumn{6}{|l|}{ Tinnitus } \\
\hline No & $44(80.0 \%)$ & 47 (85.5\%) & 1 & & \\
\hline Yes & $11(20.0 \%)$ & $8(14.6 \%)$ & 1.47 & {$[0.54-4.12]$} & $0.449^{*}$ \\
\hline \multicolumn{6}{|l|}{ Vertigo } \\
\hline No & $54(98.2 \%)$ & $55(100 \%)$ & - & - & \\
\hline Yes & $1(1.8 \%)$ & $0(0.0 \%)$ & - & - & $1.000^{* *}$ \\
\hline \multicolumn{6}{|l|}{ Otalgia } \\
\hline No & $53(96.4 \%)$ & $55(100.0 \%)$ & - & & \\
\hline Yes & $2(3.6 \%)$ & $0(0.0 \%)$ & - & - & $0.495^{* *}$ \\
\hline \multicolumn{6}{|l|}{ Otorrhea } \\
\hline No & $54(98.2 \%)$ & $55(100.0 \%)$ & & & \\
\hline Oui & $1(1.8 \%)$ & $0(0.0 \%)$ & - & - & $1.000^{* *}$ \\
\hline Headache & & & - & - & \\
\hline No & $51(92.7 \%)$ & $55(100.0 \%)$ & - & - & \\
\hline Yes & $4(7.3 \%)$ & $0(0.0 \%)$ & - & - & $0.118^{* *}$ \\
\hline
\end{tabular}

${ }^{\star}$ Peason's Chi-squared Test; ${ }^{*}$ Fisher's Exact Test. 
otitis media was also cured after ten days of antibiotic therapy with amoxicillinclavulanic acid combined with paracetamol. The military personnel involved performed the audiometry at a distance from the infectious episode.

\section{- Audiometric parameters}

Baseline pure tone audiometry revealed 30 cases of hearing loss, 23 of which were in the exposed population (Table 4 ). The hearing loss was typically mild ( $\mathrm{p}$ $=0.002)$ and bilateral $(\mathrm{p}=0.007)$.

\section{- Analysis of hearing loss on pure tone audiometry}

There was a statistically significant relationship between hearing loss and noise exposure in both ears (Table 5).

\section{- Factors Associated with Hearing Loss}

Table 4. Relationship between the characteristics of the hearing loss and the exposure to noise.

\begin{tabular}{|c|c|c|c|c|c|}
\hline & $\begin{array}{c}\text { Exposed } \\
\mathrm{n}(\%)\end{array}$ & $\begin{array}{c}\text { Controls } \\
\text { n (\%) }\end{array}$ & OR & CI95\% & p-value \\
\hline Type of hearing loss & & & & & $0.005^{\star}$ \\
\hline Normal & $32(58.2 \%)$ & $48(87.3 \%)$ & 1.00 & & \\
\hline Conductive & $5(9.1 \%)$ & $2(3.6 \%)$ & 3.75 & {$[0.76-27.31]$} & 0.127 \\
\hline Sensorineural & $14(34.5 \%)$ & $4(7.3 \%)$ & 5.25 & {$[1.71-19.84]$} & 0.007 \\
\hline Mixed & $4(7.3 \%)$ & $1(1.8 \%)$ & 6.00 & [0.84 - 120.27] & 0.127 \\
\hline Degree of hearing loss & & & & & $0.001^{\star}$ \\
\hline Normal & $32(58.2 \%)$ & $48(87.3 \%)$ & 1.00 & & \\
\hline Mild & $21(38.2 \%)$ & $7(12.7 \%)$ & 4.50 & {$[1.78-12.57]$} & 0.002 \\
\hline Moderate & $2(3.6 \%)$ & $0(0 \%)$ & - & - & 0.988 \\
\hline Laterality & & & & & $0.001^{\star}$ \\
\hline Normal hearing & $32(58.1)$ & $48(87.3)$ & 1.00 & & \\
\hline $\begin{array}{l}\text { Bilateral and } \\
\text { asymmetric }\end{array}$ & $13(23.6)$ & $6(10.9)$ & 3.25 & {$[1.16-10.08)$} & 0.030 \\
\hline $\begin{array}{l}\text { Bilateral and } \\
\text { symmetric }\end{array}$ & $10(18.2)$ & $1(1.8)$ & 15.00 & {$[2.68-282.01]$} & 0.012 \\
\hline
\end{tabular}

${ }^{\star}$ Fisher's Exact Test.

Table 5. Correlation between hearing loss (in $\mathrm{dB}$ ) and group membership.

\begin{tabular}{lccc}
\hline & $\begin{array}{c}\text { Exposed } \\
\text { Mean } \pm \text { standard deviation }\end{array}$ & $\begin{array}{c}\text { Controls } \\
\text { Mean standard deviation }\end{array}$ & p-value \\
\hline $\begin{array}{c}\text { Hearing Loss } \\
\text { Right Ear }\end{array}$ & $92.6 \pm 29.5$ & $70.7 \pm 11.3$ & $0.012^{*}$ \\
$\begin{array}{c}\text { Hearing Loss } \\
\text { Left Ear }\end{array}$ & $102.9 \pm 29.0$ & $71.7 \pm 17.5$ & $0.000^{*}$ \\
\hline
\end{tabular}

*Student's Test. 
In addition, there is a statistically significant relationship between hearing loss, age and duration of exposure at the exposed level (Table 6).

Table 6. Correlation between hearing loss, age and duration of exposure.

\begin{tabular}{ccccc}
\hline & \multicolumn{4}{c}{ Hearing Loss $(\mathrm{dB})$} \\
\cline { 2 - 5 } & \multicolumn{3}{c}{ Exposed } & \multicolumn{2}{c}{ Controls } \\
\cline { 2 - 5 } & Cor. Coef* & p-value & Cor. Coef. & p-value \\
\hline Age & 0.320 & $0.017^{\star *}$ & 0.144 & $0.293^{\star *}$ \\
Duration of exposure & 0.286 & $0.034^{* *}$ & 0.118 & $0.393^{\star *}$ \\
\hline
\end{tabular}

${ }^{\star}$ Correlation coefficient. ${ }^{\star}$ Pearson correlation.

\section{Discussion}

The study was conducted to assess otologic morbidity and measure noise exposure of military music professionals in Cotonou. This is the first study to include systematic diagnostic tone audiometry in military musicians of the Beninese Armed Forces (FAB).

\subsection{Socio-Demographic Characteristics}

\section{Age}

The study was conducted on a sample of young adult military personnel in full professional activity. Ndiaye et al. [5] in 2013 and Diop et al. [6] in 2017 in Senegal reported respectively during their studies on military personnel average ages of 39.7 years and 36.6 years similar to the average age found in our study. These study results could be explained by the fact that in Benin, recruitment into the army is open to young people between the ages of 18 and 25 for a period of 30 to 35 years depending on the military rank. The age homogeneity of the two groups was simply achieved by the fact that they all came from the same Beninese military population. Gonçalves et al. [7] in a retrospective cohort study of hearing threshold analysis in Brazilian military musicians, also found age homogeneity between the military musician group $(34.9 \pm 7.8$ years $)$ and the control group (35.4 \pm 9.4 years). The inclusion criteria excluded military personnel, whether musicians or not, over 50 years of age. These were military personnel on the verge of retirement, for whom presbycusis could be a confounding factor. Although there is a large inter-individual variability, the age of onset would be around 50 years [8]. In the United States, presbycusis affects about half of the population over the age of 65 [9]. It is recommended that adults be screened systematically for hearing loss from the age of 60 [10].

\section{Gender}

The low female representation in the sample is a reflection of the gender distribution in Benin Army. Like all occupations requiring physical strength, the military function has long been considered a "man's job" and every man is potentially a warrior [11]. However, one cannot deny the historical role played by 
the Amazonian women of Dahomey in certain military operations in Benin's history. The low participation of women in music is also a fact explained by authors including Sergeant et al. [12] in 2019 in England. These authors [12] counted $39.7 \%$ women out of a total of 3420 musicians in 40 world-class symphony orchestras spread across three regions (the United Kingdom, Europe and the United States). The sexist reasons that historically justified discrimination against women have been dispelled since the second half of the 20th century [12]. However, the influence of gender as a biological variable in the occurrence of deafness is still poorly understood [13]

\subsection{Noise Exposure Analysis}

The measured sound levels are above the recommended standards according to the daily exposure time, since for a maximum daily exposure time of one hour, the equivalent weighted sound level should be $94 \mathrm{~dB}$ (A). Gonçalves et al. [7] evaluated the sound pressure levels to which military musicians in Brazil were exposed using an integrated sound level meter. They reported that, during rehearsal sessions lasting 4 hours, these levels varied from 90.1 to $110.3 \mathrm{~dB}$ (A). A Canadian study by Qian et al. [14] found that the average sound levels of ballet orchestra musicians playing wind instruments for 3 hours were between 88 and $94 \mathrm{~dB}$ (A). In Germany, Schmidt et al. [15] measured the noise exposure of symphony orchestra musicians and reported sound levels between 82 and $98 \mathrm{~dB}$ (A). Nataletti P et al. [16] reported in a study of national orchestra musicians in Italy that musicians are subjected to high personal daily sound levels that can systematically exceed $85 \mathrm{~dB}(\mathrm{~A})$ in the case of percussionists. In Portugal, Rodrigues et al. [17] also reported high noise levels in the context of an evaluation of the exposure to noise of musicians in a Portuguese symphony orchestra. Measurements made with the dosimeter and a sound level meter in this study noted for wind instruments, a sound level that averaged $92.7 \pm 2.77 \mathrm{~dB}$ (A) and $90.0 \pm 2.93 \mathrm{~dB}(\mathrm{~A})$ for percussion. Lower noise levels were measured for string instruments, which were evaluated at $85.4 \pm 3.40 \mathrm{~dB}$ (A). The similarity of these results showing overall exposure to high sound intensities could be due to the rather similar instrumental composition that exists in these different groups. On the other hand, these high and fluctuating sound levels could be explained by the complexity of the sounds emitted by a music group. Thus, it should be noted that several factors make the sound level emitted by a group of musicians very changeable. These include the variability of instrumentation within bands, the position of musicians in relation to bands or in an orchestra, the chosen musical repertoire, the location of rehearsal or performance, and individual variability such as musician fatigue. In this study, military musicians were exposed to these sound levels that were too high for the duration of exposure. This level of exposure is sufficient to generate permanent hearing impairment. Thus, the Brazilian study by Gonçalves et al. [7] found greater hearing loss in military musicians who had been exposed for more than 21 years. A German study evaluating the 
hearing status of professional classical orchestra musicians and music students showed that more than $50 \%$ of the musicians had a hearing loss of $15 \mathrm{~dB}(\mathrm{~A})$ or more [18]. The highest losses were found among string and brass instrument players. These authors therefore concluded that musicians need the same health care for their hearing as workers in noisy industry. Reinhard Müller and Joachim Schneider [19] conducted a prospective study on a group of 36 German military musicians seen at 13-year intervals. Despite the high noise levels, the average hearing ability of the 36 military musicians during the investigation period deteriorated only slightly in the noise-sensitive frequencies $(3,5$ and $6 \mathrm{kHz})$. These results suggest that music may be less harmful than industrial noise.

In our sample, none of these music professionals routinely wore hearing PPE. The survey also shows that noise exposure goes beyond the military music profession for some subjects. Indeed, musical initiation elicited dual noise exposures: professional and extra-professional. This study did not quantify loudness in the context of music practiced for recreational and/or religious purposes.

\subsection{Otological Symptoms}

The main otological symptoms found in military musicians were deafness (41.8\%) followed by tinnitus (20\%) and headache (7.3\%). These are classic and well known causes of occupational exposure to noise pollution [20]. Moreover, there is a statistically significant relationship between the occurrence of deafness and noise exposure $(\mathrm{p}<0.001)$. Souleymane et al. [21], in analyzing the health and social impact of noise pollution among power plant workers in the city of Ouagadougou in Burkina Faso, reported 11.7\% headaches and 34\% deafness. Foma et al. [22] in a hospital study found that tinnitus was frequently associated with deafness and headache in $66 \%$ and $31.1 \%$ of cases respectively and that noise trauma was the main etiology. It should be noted that deafness induced by occupational noise exposure has been reported extensively in the literature [3] [23] [24]. Tinnitus is also a recurrent problem [25].

Numerous studies have reported a similar symptomatology to ours but in different proportions. In Brazil, in 2009, musicians of military bands were also evaluated. A study with 50 subjects had revealed that $76 \%$ of the musicians had tinnitus and 54\% reported hearing difficulties [26]. Also, Luders D et al. [27] found in 2016 as auditory symptoms in a study with 100 musicians, $72 \%$ tinnitus and 67\% intolerance to loud sounds. In Australia, O’Brien I et al. [28] reported on 367 musicians from eight professional orchestras, $43 \%$ deafness, $42 \%$ tinnitus experienced sometimes and $9 \%$ persistently.

\subsection{Hearing Assessment for Military Musicians}

Repetitive noise exposure is one of the major preventable sources of permanent hearing loss. The collected hearing losses were significantly higher in the military musician group (41.8\%). The study also found a statistically significant relationship between hearing loss and noise exposure $(p=0.001)$. Also, it should be 
noted that the military musician had a 4.50 times greater risk of developing a mild hearing loss than a non-musician (OR 95\% = [1.78 - 12.57]). The risk of sensorineural hearing loss was 5.25 times higher in the noise-exposed group compared to the control group $(\mathrm{OR} 95 \%=[1.71-19.84])$. This could be explained by the fact that noise causes damage to the inner ear which leads to sensorineural hearing loss [20] [24]. Indeed, in case of auditory nuisance, the hair cells of the inner ear are damaged and cannot regenerate. Recent studies have demonstrated a vulnerability of the inner ear during long exposures such as the case of the musicians in the present study [29] [30] [31]. Russo F et al. [32] [33] also reported the existence of sensorineural hearing loss in 2012 and 2017 in their study of 52 musicians of the National Ballet Orchestra of Canada.

Classically, noise-induced hearing loss is a bilateral and symmetrical hearing loss [24] [34]. The bilateral and symmetrical hearing losses in the study were ten times greater in military musicians $(18.2 \%)$ than in non-musicians $(1.3 \%)$. The asymmetry observed in our study (23.6\% in the exposed group and $10.9 \%$ in the controls) does not call into question their aetiology [20] [35] [36]. The characteristic of symmetry of the hearing loss should therefore be considered with reservation as being specific to a noise-induced hearing loss. This risk of military music-induced hearing loss can be as high as 14.54 times compared to the control group [7]. However, this risk is non-existent at the beginning of the career [37]. The deafness found in our sample was proportional to the age and duration of exposure at the level of the exposed. Sayegh Ghoussoub M et al. [38] in Lebanon published similar results among musicians playing a wind instrument in the orchestras of the national conservatory of the Lebanese army and the internal security forces. Even though deafness is noise-induced, the age of the musician is an additional etiological factor [39].

Hearing damage related to sound trauma is manifested by a notch centered at 3, 4, or $6 \mathrm{kHz}$. The $4000 \mathrm{~Hz}$ frequency is the most affected and is therefore found in the center of the notch on tone audiometry [24]. The more intense and repeated the sound trauma, the more these notches increase in width and depth, indicating a greater destruction of the hair cells in this most fragile frequency zone of the ear [40]. The study by Schmidt JH et al. [41] found that occupational noise exposure in five groups of symphony orchestra musicians led to noiseinduced hearing loss with higher hearing thresholds between 3 and $6 \mathrm{kHz}$. The largest noise-related effects on audiograms in the said study were shown at 3 and $4 \mathrm{kHz}$. For Emmerich et al. [18] and Jansen et al. [42], hearing loss was predominant at $4 \mathrm{kHz}$ or $6 \mathrm{kHz}$. This aspect appears to be the most specific for noise-induced hearing loss.

Conventional audiometry showed that the most significant hearing loss in the military musicians in our study was in the $250 \mathrm{~Hz}$ and $500 \mathrm{~Hz}$ frequencies. In all cases, primary prevention and early detection with a view to appropriate treatment will help to maintain better hearing health. The golden rule is regular medical follow-up and the use of hearing protection equipment. Hearing as- 
sessment should be done at the first sign of doubt, without wasting time, and should include a clinical examination and pure tone audiometry. Hearing protectors specially designed for music professionals help maintain good hearing and acoustic accuracy. They can be custom-made based on the impressions of the external acoustic meatus. Workplace noise legislation in our country does not provide specific guidance for musicians or a code of conduct that sets general guidelines on how musicians should be protected from noise exposure. This is particularly critical since the hearing ability of musicians is crucial to their professional activity and performance.

\section{Conclusion}

The study conducted among military musicians showed that this is a young adult population, mostly male. The results suggest that military musicians are exposed to high noise levels, putting them at risk of developing hearing problems that may limit their performance. The main otological morbidity found was deafness associated with a few cases of tinnitus and headache. The imputability of occupational exposure was not clearly established because of the non-specific aspect of the audiometry and the notion of extra-occupational noise exposure. In view of the importance of good hearing health for military musicians in the performance of their duties, the implementation of a prevention program is essential.

\section{Conflicts of Interest}

The authors declare no conflicts of interest regarding the publication of this paper.

\section{References}

[1] Chatti, S., Rhif, H., Maoua, M., Boukadida, K., Abbassi, A., Mlaouah, A.J., et al. (2010) Surdité professionnelle dans une industrie automobile de la région du centre Tunisien reconnaissance et indemnisation. Journal Tunisien d ORL et de Chirurgie Cervico-Faciale, 25, 6-11.

[2] World Health Organization. Deafness Prevention [Internet]. https://pubmed.ncbi.nlm.nih.gov/26276949/www.who.int/pbd/deafness/estimates/e $\underline{\mathrm{n}}$

[3] Shi, L., Chang, Y., Li, X., Aiken, S., Liu, L. and Wang, J. (2016) Cochlear Synaptopathy and Noise-Induced Hidden Hearing Loss. Neural Plasticity, 2016, Article ID: 6143164. https://doi.org/10.1155/2016/6143164

[4] Smith, C., Beamer, S., Hall, S., Helfer, T. and Kluchinsky, T.A. (2015) A Preliminary Analysis of Noise Exposure and Medical Outcomes for Department of Defense Military Musicians. U.S. Army Medical Department Journal, 3, 76-82.

[5] Aziz, N.A., Mohamed, S.S., Badara, T.A., Boubacar, G., Gallo, S.P., Awa, G., et al. (2015) Les maladies chroniques non transmissibles chez les militaires sénégalais: Étude transversale en 2013. The Pan African Medical Journal, 22, 59. https://doi.org/10.11604/pamj.2015.22.59.4777

[6] Dio, M., Diou, A., Seck, S.M., Lo, G., Ka, D., Massaly, A., et al. (2017) Prévalence de l'antigène de surface du virus de l'hépatite $B$ et facteurs associés chez des militaires 
sénégalais envoyés en mission au Darfour. The Pan African Medical Journal, 26, 1-9. https://doi.org/10.11604/pamj.2017.26.154.11594

[7] Gonçalves, C.G.O., Lacerda, A.B.M., Zeigelboim, B.S., Marques, J.M. and Luders, D. (2015) Auditory Thresholds among Military Musicians: Conventional and High Frequency. Codas, 25, 181-187. https://doi.org/10.1590/S2317-17822013000200015

[8] Chérot-Kornobis, N. and Douchement, D. (2014) Presbyacousie et travail. Archives des Maladies Professionnelles et de P Environnement, 75, 522-524. https://doi.org/10.1016/j.admp.2014.07.029

[9] Kidd, A.R. and Bao, J. (2012) Recent Advances in the Study of Age-Related Hearing Loss-A Mini-Review. Gerontology, 58, 490-496.

https://doi.org/10.1159/000338588

[10] Guinchard, A.C., Estoppey, P. and Maire, R. (2017) Presbyacousie: Baisse de l'ouïe chez la personne âgée-Forum Médical Suisse. Forum Médical Suisse, 17, 230-235. https://doi.org/10.4414/fms.2017.02881

[11] Prévot, E. (2010) Féminisation de l'armée de terre et virilité du métier des armes. Cahiers du Genre, 48, 81-101. https://doi.org/10.3917/cdge.048.0081 https://www.cairn.info/revue-cahiers-du-genre-2010-1-page-81.htm

[12] Sergeant, D.C. and Himonides, E. (2019) Orchestrated Sex: The Representation of Male and Female Musicians in World-Class Symphony Orchestras. Frontiers in Psychology, 10, Article No. 1760. https://doi.org/10.3389/fpsyg.2019.01760

[13] Villavisanis, D.F., Berson, E.R., Lauer, A.M., Cosetti, M.K. and Schrode, K.M. (2020) Sex-Based Differences in Hearing Loss: Perspectives from Non-Clinical Research to Clinical Outcomes. Otology \& Neurotology, 41, 290-298. https://doi.org/10.1097/MAO.0000000000002507

[14] Qian, C.L., Behar, A. and Wong, W. (2011) Noise Exposure of Musicians of a Ballet Orchestra. Noise and Health, 13, 59-63. https://doi.org/10.4103/1463-1741.74000

[15] Schmidt, J.H., Pedersen, E.R., Juhl, P.M., Christensen-Dalsgaard, J. andersen, T.D., Poulsen, T., et al. (2011) Sound Exposure of Symphony Orchestra Musicians. The Annals of Occupational Hygiene, 55, 893-905.

[16] Nataletti, P., Sisto, R., Pieroni, A., Sanjust, F. and Annesi, D. (2007) Pilot Study of Professional Exposure and Hearing Functionality of Orchestra Musicians of a National Lyric Theatre. Giornale Italiano di Medicina del Lavoro ed Ergonomia, 29, 496-498.

[17] Rodrigues, M.A., Freitas, M.A., Neves, M.P. and Silva, M.V. (2014) Evaluation of the Noise Exposure of Symphonic Orchestra Musicians. Noise \& Health, 16, 40-46. https://doi.org/10.4103/1463-1741.127854

[18] Emmerich, E., Rudel, L. and Richter, F. (2008) Is the Audiologic Status of Professional Musicians a Reflection of the Noise Exposure in Classical Orchestral Music? European Archives of Oto-Rhino-Laryngology, 265, 753-758. https://doi.org/10.1007/s00405-007-0538-z

[19] Müller, R. and Schneider, J. (2018) Noise Exposure and Auditory Thresholds of Military Musicians: A Follow-Up Study. Journal of Occupational Medicine and Toxicology, 13, 14. https://doi.org/10.1186/s12995-018-0196-7

[20] Le, T.N., Straatman, L.V., Lea, J. and Westerberg, B. (2017) Current Insights in Noise-Induced Hearing Loss: A Literature Review of the Underlying Mechanism, Pathophysiology, Asymmetry, and Management Options. Journal of Otolaryngology-Head \& Neck Surgery, 46, 41. https://doi.org/10.1186/s40463-017-0219-x

[21] Oubian, S., Lankoandé, M. and Gyebré, Y. (2019) Impact des Nuisances Sonores sur 
la Qualité de Vie des Travailleurs dans les Centrales Électriques de la Ville de Ouagadougou. European Scientific Journal, 15, 142. https://doi.org/10.19044/esj.2019.v15n9p142

[22] Foma, W., Amana, B., Lawson, S., Pegbessou, E., Tagba, E., Dolou, W., et al. (2018) Profil des acouphènes subjectifs de l'adulte en milieu hospitalier au Togo. Cas du CHU Sylvanus Olympio de Lomé. Médecine d Afrique Noire, 65, 209-216. http://www.santetropicale.com/manelec/fr/resume oa.asp?id article $=3151$

[23] Masterson, E.A., Tak, S., Themann, C.L., Wall, D.K., Groenewold, M.R., Deddens, J.A., et al. (2013) Prevalence of Hearing Loss in the United States by Industry. American Journal of Industrial Medicine, 56, 670-681. https://doi.org/10.1002/ajim.22082

[24] Kirchner, D.B., Evenson, E., Dobie, R.A., Rabinowitz, P., Crawford, J., Kopke, R., et al. (2012) Occupational Noise-Induced Hearing Loss: ACOEM Task Force on Occupational Hearing Loss. Journal of Occupational and Environmental Medicine, 54, 106-108. https://doi.org/10.1097/JOM.0b013e318242677d

[25] Masterson, E.A., Themann, C.L., Luckhaupt, S.E., Li, J. and Calvert, G.M. (2016) Hearing Difficulty and Tinnitus among U.S. Workers and Non-Workers in 2007. American Journal of Industrial Medicine, 59, 290-300. https://doi.org/10.1002/ajim.22565

[26] Gonçalves, C.G.O., Lacerda, A.B.M., Zocoli, A.M.F., Oliva, F.C., Almeida, S.B. and Iantas, M.R. (2009) Percepção e o impacto da música na audição de integrantes de banda militar. Revista da Sociedade Brasileira de Fonoaudiologia, 14, 515-520. https://doi.org/10.1590/S1516-80342009000400015

[27] Luders, D., Goncalves, C.G.O., Lacerda, A.B.M., da Silva, L.S.G., Marques, J.M. and Sperotto, V.N. (2016) Occurrence of Tinnitus and Other Auditory Symptoms among Musicians Playing Different Instruments. The International Tinnitus Journal, 20, 48-53. https://doi.org/10.5935/0946-5448.20160009

[28] O’Brien, I., Ackermann, B.J. and Driscoll, T. (2014) Hearing and Hearing Conservation Practices among Australia's Professional Orchestral Musicians. Noise \& Health, 16, 189-195. https://doi.org/10.4103/1463-1741.134920

[29] Liberman, M.C., Epstein, M.J., Cleveland, S.S., Wang, H. and Maison, S.F. (2016) Toward a Differential Diagnosis of Hidden Hearing Loss in Humans. PLoS ONE, 11, e0162726. https://doi.org/10.1371/journal.pone.0162726

[30] Fujioka, M., Okano, H. and Edge, A.S. (2015) Manipulating Cell Fate in the Cochlea: A Feasible Therapy for Hearing Loss. Trends in Neurosciences, 38, 139-144. https://doi.org/10.1016/j.tins.2014.12.004

[31] Themann, C.L. and Masterson, E.A. (2019) Occupational Noise Exposure: A Review of Its Effects, Epidemiology, and Impact with Recommendations for Reducing Its Burden. The Journal of the Acoustical Society of America, 146, 3879-3905. https://doi.org/10.1121/1.5134465

[32] Russo, F.A., Behar, A., Chasin, M. and Mosher, S. (2012) Noise Exposure and Hearing Loss in Classical Orchestra Musicians. International Journal of Industrial Ergonomics, 6, 474-478. https://doi.org/10.1016/j.ergon.2012.11.001

[33] Behar, A., Chasin, M., Mosher, S., Abdoli-Eramaki, M. and Russo, F.A. (2018) Noise Exposure and Hearing Loss in Classical Orchestra Musicians: A Five-Year FollowUp. Noise \& Health, 20, 42-46.

[34] Chakroun, A., Achour, I., Charfeddine, I., Mnejja, M., Hammam, B. and Ghorbe, A. (2013) Evaluation de la surdité professionnelle dans un département du sud tunisien. Journal Tunisien d ORL, 30, 43-46. https://www.ajol.infojtdorlarticle 
[35] Fernandes, S.V. and Fernandes, C.M. (2010) Medicolegal Significance of Asymmetrical Hearing Loss in Cases of Industrial Noise Exposure. The Journal of Laryngology \& Otology, 124, 1051-1055. https://doi.org/10.1017/S0022215110001258

[36] Masterson, L., Howard, J., Liu, Z.W. and Phillips, J. (2016) Asymmetrical Hearing Loss in Cases of Industrial Noise Exposure: A Systematic Review of the Literature. Otology \& Neurotology, 37, 998-1005. https://doi.org/10.1097/MAO.0000000000001104

[37] Patil, M.L., Sadhra, S., Taylor, C. and Folkes, S.E.F. (2013) Hearing Loss in British Army Musicians. Occupational Medicine, 63, 281-283. https://doi.org/10.1093/occmed/kqt026

[38] Sayegh Ghoussoub, M., Ghoussoub, K., Chaaya, A., Sleilaty, G., Joubre, I. and Rifaï, K. (2008) Problèmes spécifiques de la sphère oro-maxillo-faciale et de l'ouïe chez 340 musiciens libanais pratiquant les instruments à vent. Le Journal Medical Libanais, 56, 159-167.

http://www.lebanesemedicaljournal.org/articles/56-3/original3.pdf

[39] Albera, R., Lacilla, M., Piumetto, E. and Canale, A. (2010) Noise-Induced Hearing Loss Evolution: Influence of Age and Exposure to Noise. European Archives of Oto-Rhino-Laryngology, 267, 665-671. https://doi.org/10.1007/s00405-009-1096-3

[40] Meyer-Bisch, C. (2005) Hypoacousie due au bruit: La réglementation évolue. Medical Sciences (Paris), 21, 1089-1095. https://doi.org/10.1051/medsci/200521121089

[41] Schmidt, J.H., Pedersen, E.R., Paarup, H.M., Christensen-Dalsgaard, J., Andersen, T., Poulsen, T., et al. (2014) Hearing Loss in Relation to Sound Exposure of Professional Symphony Orchestra Musicians. Ear and Hearing, 35, 448-460. https://doi.org/10.1097/AUD.0000000000000029

[42] Jansen, E.J.M., Helleman, H.W., Dreschler, W.A. and de Laat, J.A.P.M. (2009) Noise Induced Hearing Loss and Other Hearing Complaints among Musicians of Symphony Orchestras. International Archives of Occupational and Environmental Health, 82, 153-164. https://doi.org/10.1007/s00420-008-0317-1 


\section{Questionnaire}

\section{NOICE EXPOSURE AND OTOLOGICAL MORBIDITY IN MILITARY MUSICIANS IN COTONOU}

\section{Information note for individual free consent}

I am Alexis do Santos Zounon, a medical doctor in charge of an investigation on the "Noise exposure and ontological morbidity of military musicians in Cotonou".

The results will inform us about the noise exposure and ontological morbidities of military musicians in Cotonou. At the end of our study, strategies for better management of hearing health will be proposed to the competent authorities. We therefore ask you to respond in a simple and since remanner to ensure the reliability of the data.

The data will be processed anonymously. Your consent is required for participation in the study.

Informed consent obtained:

$$
1=\mathrm{YES} / \_/ \quad 2=\mathrm{NO} /
$$

Date Signature

NOICE EXPOSURE AND OTOLOGICAL MORBIDITY IN MILITARY MUSICIANS IN COTONOU

\begin{tabular}{l}
\hline \multicolumn{2}{c}{ QUESTIONNAIRE } \\
$\mathrm{N}^{\bullet}$ Question \\
IDENTIFICATION \\
Identification Number \\
Date of registration \\
Full name of the investigator
\end{tabular}

SOCIO-DEMOGRAPHIC PARAMETERS

1 How old are you?

I_I

2 Gender

Female $=0$

Male $=1$

BACKGROUND

3 Cranial trauma

$$
\mathrm{No}=0
$$

Yes $=1$ 
4 Persistent or repeated otologic infections

No $=0$

Yes $=1$

5 Tumor

No $=0$

Yes $=1$

6 Otologic Surgery

No $=0$

Yes $=1$

7 Use of ototoxic medication

No $=0$

Yes $=1$

8 Other

\section{OCCUPATIONAL FACTORS AND NOISE EXPOSURE}

9 Current battalion

$1^{\text {st } C a m p ~ G u e ́ z o ~ M o t o r i z e d ~ / ~ / ~}$

Intervention Battalion $=0$

Music Squadron $=1$

10 What is your seniority in the army (year)

11 What is your seniority in the music squadron / _ _ _ (year)

12 What musical instrument do you play?

String instruments $=0 \ldots \ldots /$ Percussion $=1$.

Wind instruments $=2 \ldots \ldots$

13 How many days per week do you practice

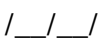

music (professional practice)

14 How many hours do you practice music per day (professional practice)

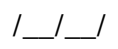

15 Noise level of the working environment

$$
1
$$

\section{BEHAVIOURAL FACTORS}

16 Do you wear hearing protection?

$$
\begin{aligned}
& \text { No }=0 \\
& \text { Yes }=1 \\
& \text { No }=0 \\
& \text { Yes }=1
\end{aligned}
$$

17 Do you practice music

\section{MORBIDITES}

$\begin{array}{ll}18 \text { Otorrhea } & \text { No }=0 \\ & \text { Yes }=1 \\ 19 \text { Otalgia } & \text { No }=0 \\ & \text { Yes }=1 \\ & \text { No }=0 \\ 20 \text { Tinnitus } & \text { Yes }=1 \\ & \text { No }=0 \\ 21 \text { Hearing loss } & \text { Yes }=1\end{array}$

22 Other

Audiometric Parameters 
23 Average hearing loss in the right ear

24 Average hearing loss in the left ear

25 Type of hearing loss
I_I_I

$1+1$

Conductive $=0$

I_I

Sensorineural $=1$

Mixed $=2$ 